\title{
Evaluation of ELISA for the Detection of Toxoplasma Antibodies in Swine Sera
}

\author{
By Varpu Hirvelä-Koski \\ National Veterinary Institute, Department of Hygiene, Helsinki, Finland.
}

\begin{abstract}
Hirvelä-Koski, V: Evaluation of ELISA for the detection of Toxoplasma antibodies in swine sera. Acta vet. scand. 1990, 31, 413-422. - Enzyme-linked immunosorbent assay (ELISA) is compared with the indirect fluorescent antibody test (IFAT), the indirect haemagglutination test (IHAT) and the latex agglutination (LA) test for the detection of toxoplasma antibodies in swine sera. The 100 swine sera examined represent ELISA values from $>0$ to 154 EIU. The agreement was highest (0.67) between ELISA and IFAT with an ELISA cut-off value of $30 \mathrm{EIU}$, and between ELISA and the LA test with an ELISA cut-off value of 50 EIU (0.74). All sera giving $<10$ EIU were negative in the other tests, and all those with $>70$ EIU were positive in 1, 2 or all of the reference tests. In order to avoid false positive results with ELISA, all sera giving 10-70 EIU should be confirmed with a test which has a good specificity, e.g. IFAT.

ELISA is a sensitive test and is highly suitable for the screening of large amounts of samples, but it may be too complicated for screening toxoplasma antibodies in the laboratories of abattoirs.
\end{abstract}

IFAT; IHAT; latex agglutination test.

\section{Introduction}

Toxoplasmosis is a worldwide parasite zoonosis. Toxoplasma gondii undergoes a coccidian cycle in the intestinal epithelium of cats which results in the shedding of oocysts in the cat faeces (Hutchison et al. 1970). Other animals, including man, serve as intermediate hosts, and may harbour toxoplasma tissue cysts in their musculature or other organs. Toxoplasma infection can be transmitted to humans by ingestion of either tissue cysts or oocysts. The foetus may be infected congenitally through trophozoites, the parasitic form of $T$. gondii circulating in the blood during the acute phase of infection. The reactivation of a latent toxoplasma infection in immunosuppressed patients can lead to a clinical disease, e.g. toxoplasmic encephalitis in patients with AIDS ( $L u f t \&$ Remington 1988).

Raw or inadequately cooked pork is considered to be an important source of toxo- plasma tissue cysts (Boch 1973, Dubey et al. 1986). They are not visible, and carcasses harbouring cysts cannot be identified by conventional meat inspection methods. Because the parasitological methods used for the detection of toxoplasma cysts are very laborious, the diagnosis of toxoplasmosis is usually based on serology. Even though not every pig with a positive antibody titre harbours toxoplasma tissue cysts, the appearance of toxoplasma antibodies is associated with the presence of viable $T$. gondii organisms in the meat or other organs of swine. The methylene blue dye test, indirect fluorescent antibody test (IFAT), indirect haemagglutination test (IHAT), latex agglutination (LA) test and enzyme-linked immunosorbent assay (ELISA) are used for the detection of toxoplasma antibodies. When used for screening purposes, ELISA has some advantages over the other methods. It can be semiautomated and the reading of the results 
is objective and does not require skilled personnel, as does IFAT, for instance, which relies on a subjective interpretation of the microscope reading. Like IFAT, ELISA can distinguish between immunoglobulin classes, which the LA test cannot do. ELISA has been considered a suitable method for screening for swine toxoplasmosis, and its possible use at abattoirs for the inspection of individual animals has also been discussed (van Knapen et al. 1982, Oliver et al. 1983, Waltman et al. 1984).

The purpose of this investigation was to evaluate ELISA as a screening method for the detection of toxoplasma antibodies in swine sera in connection with meat inspection at abattoirs.

\section{Material and methods}

\section{Test sera}

A total of 100 sera were chosen from a group of 1849 swine sera obtained from Finnish slaughter houses from clinically healthy pigs. All 1849 sera were examined for toxoplasma antibodies by ELISA. The 100 sera used in this study were chosen to represent various ELISA values ranging from < 0 to 154 EIU which was the highest ELISA value measured. The ELISA results were compared with those obtained by IFAT, IHAT and the LA test.

\section{Positive control sera}

Positive control sera were produced in 2 pigs, about $18 \mathrm{~kg}$ each, which were inoculated subcutaneously with Toxoplasma gondii (T.g.) trophozoites obtained from the peritoneal exudate of mice infected intraperitoneally with T.g. Pig 1 was inoculated with $10,000,2,000,000$ and 75,000 trophozoites and pig 2 with 20,000, 2,000,000 and 150,000 trophozoites at 2-3 weeks intervals. Blood samples were taken weekly and the sera examined for toxoplasma antibodies by the indirect haemagglutination test (ToxoHA Kit, bioMérieux, France).

No toxoplasma antibodies could be detected in the sera of these pigs before the first inoculation (IHA titres < 10). When the IgG titres had reached a plateau $40-80$ in pig 1 and 160-320 in pig 2, the pigs were anaesthetized and bled. The sera were stored at $-20^{\circ} \mathrm{C}$ after centrifugation.

\section{Enzyme-linked immunosorbent assay (ELISA)}

The serum of pig 2 was used as a positive control, while a negative control serum was obtained by pooling 5 porcine sera which had been negative either by IFAT or IHAT and which had ELISA absorbance values of about 0.1 or less. The pool was stored at $-20^{\circ} \mathrm{C}$.

Microtitre plates coated with toxoplasma antigen were prepared by Labsystems Oy (Helsinki, Finland) by the method described by Turunen (1983). These flat-bottomed polystyrene microtitre plates were sensitized with this antigen preparation to the degree that the positive control serum (pig 2) and the negative control serum gave absorbance values of about 1.0 and 0.1 , respectively. The plates were stored at $+6^{\circ} \mathrm{C}$.

The control sera and test sera were diluted 1:200 in phosphate-buffered saline (PBS) (Labsystems OY) and added to the microtitre plates in duplicate, $0.1 \mathrm{ml}$ in each well. The positive and negative control sera were included in each plate. The reagent blank wells received $0.1 \mathrm{ml}$ of the diluent buffer.

The plate was covered and incubated for 90 min at $37^{\circ} \mathrm{C}$, after which the sera were discarded and the wells washed 3 times with Tween 20 diluted 1:500 with $0.9 \%(w / v)$ $\mathrm{NaCl}$.

Alkaline phosphatase conjugated sheep antibodies to swine IgG (Orion Diagnostica, Helsinki, Finland) were diluted 1:200 with 
PBS, and $0.1 \mathrm{ml}$ of this solution was added to each well. After incubation for $60 \mathrm{~min}$ at $37^{\circ} \mathrm{C}$, the wells were emptied and washed as described above.

The substrate solution of paranitrophenyl phosphate $20 \mathrm{mg} / \mathrm{ml}$ in diethanolamine buffer, $\mathrm{pH} 10.0$, was added $(0.1 \mathrm{ml} /$ well $)$. After incubation for $30 \mathrm{~min}$ at $37^{\circ} \mathrm{C}$, the reaction was stopped by the addition of $0.1 \mathrm{ml}$ of 1 $\mathrm{M} \mathrm{NaOH}$. The intensity of the colour reaction was measured at $405 \mathrm{~nm}$ with a Titertek Multiskan spectrophotometer (Eflab). The absorbance values of the parallel wells were averaged and the result converted to "enzyme immunoassay units" (EIU) by the following formula:

$$
\mathrm{EIU}=\frac{\left(\begin{array}{l}
\text { absorbance value } \\
\text { of the sample }
\end{array}\right)-\left(\begin{array}{l}
\text { absorbance value } \\
\text { of the negative } \\
\text { control serum }
\end{array}\right)}{\left(\begin{array}{l}
\text { absorbance value } \\
\text { of the positive } \\
\text { control serum }
\end{array}\right)-\left(\begin{array}{l}
\text { absorbance value } \\
\text { of the negative } \\
\text { control serum }
\end{array}\right)} \times 100
$$

\section{Indirect fluorescent antibody test (IFAT)}

Toxoplasma antigen was prepared from peritoneal exudate of mice infected 5 days previously. The exudate was diluted 1:1 with $3 \%$ formalin-PBS, and the suspension was left to stand for $2 \mathrm{~h}$ before being centrifuged and washed 3 times. The sediment was resuspended in a sufficient amount of PBS and small drops of this transferred to microscope slides. The slides were air dried and stored at $-20^{\circ} \mathrm{C}$.

The test was performed as described in the procedural guide of the CDC (Anon. 1980). The sera were tested at a series of dilutions increasing in two-fold steps beginning at 1:10. Incubation was for $30 \mathrm{~min}$ at $37^{\circ} \mathrm{C}$ in moist chamber. Fluorescein-conjugated antibody to swine IgG (heavy and light chainspecific $F$ (ab')2 fragment, Cappel Laboratories) diluted 1:50 with PBS containing 1:10 Evans Blue $0.06 \%$ solution was used.
The slides were examined with a fluorescence microscope. The reaction was considered positive when yellow-green fluorescence extended around the entire periphery of most of the parasites in several fields of the smear. Incomplete peripheral or faint staining was deemed negative. All the samples were tested at least twice in different test runs. To calculate the geometric mean titre, the common logarithms of the reciprocal endpoint dilutions were averaged and the result converted to its antilogarithm. A geometric mean titre $>10$ was considered positive.

\section{Indirect haemagglutination test (IHAT)}

Toxo-Ha Kits (bioMérieux, France) were used, following the manufacturers' instructions. All the samples were tested at least twice in different test runs. Geometric mean titres of the test results were calculated as for IFAT, an a titre $>20$ was considered positive.

\section{Latex agglutination ( $L A)$ test}

Toxolex kits (Orion Diagnostic, Helsinki, Finland) were used in accordance with the manufacturers' instructions with the exception that the reaction was studied for $10 \mathrm{~min}$ instead of $6 \mathrm{~min}$. All the samples were tested at least twice. The positive control sera were included in each test run, and gave positive reactions after $3 \mathrm{~min}$ for pig 2 and $7 \mathrm{~min}$ for pig 1.

\section{Results}

Comparisons between the results for ELISA and the 3 reference tests are shown in Tables 1,2 and 3, respectively. The levels of agreement between ELISA and the other tests are given in Fig. 1.

The 29 sera with 10.0 EIU or less with this ELISA were negative in all the reference tests (Fig. 2), while the 19 sera with EIU 
Table 1. Results of enzyme-linked immunosorbent assay (ELISA) and the indirect fluorescent antibody test (IFAT) with respect to 100 porcine sera examined for toxoplasma antibodies.

\begin{tabular}{|c|c|c|c|c|c|c|c|}
\hline \multirow{2}{*}{$\begin{array}{l}\begin{array}{l}\text { ELISA } \\
\text { result } \\
\text { (EIU) }\end{array} \\
\end{array}$} & \multicolumn{7}{|c|}{ IFAT titre (geom. mean) } \\
\hline & $<10$ & $10-20$ & $21-40$ & $41-80$ & $81-160$ & $161-320$ & $321-640$ \\
\hline$<0$ & $15^{1}$ & & & & & & \\
\hline $0.1-10.0$ & 14 & & & & & & \\
\hline $10.1-20.0$ & 11 & & & 1 & 1 & & \\
\hline $20.1-30.0$ & 12 & 4 & & & 2 & 2 & \\
\hline $30.1-40.0$ & 2 & 3 & 2 & & 1 & & \\
\hline $40.1-50.0$ & 1 & 1 & & & & & 1 \\
\hline $50.1-60.0$ & 2 & 1 & & & 1 & & \\
\hline $60.1-70.0$ & 1 & & 1 & 1 & 1 & & \\
\hline $70.1-80.0$ & & 1 & & & 1 & & \\
\hline $80.1-90.0$ & & & 1 & & 1 & & 1 \\
\hline $90.1-100.0$ & & & & & 1 & & \\
\hline $100.1-110.0$ & & & & & & 5 & \\
\hline $110.1-120.0$ & & & 1 & & & 2 & \\
\hline $120.1-130.0$ & & & & & & 2 & \\
\hline $130.1-140.0$ & & & & & & & \\
\hline $140.1-150.0$ & & & & & & 2 & \\
\hline $150.1-160.0$ & & & & & & & 1 \\
\hline
\end{tabular}

${ }^{1}$ Number of sera.

Table 2. Results of enzyme-linked immunosorbent assay (ELISA) and the indirect haemagglutination test (IHAT) with respect to 100 porcine sera examined for toxoplasma antibodies.

\begin{tabular}{lrlllll}
\hline \multirow{2}{*}{$\begin{array}{l}\text { ELISA } \\
\text { result } \\
\text { (EIU) }\end{array}$} & \multicolumn{5}{c}{ IHAT titre (geom. mean) } \\
\cline { 2 - 6 }$<0$ & 151 & & & & & \\
$0.1-10.0$ & 14 & & & & & \\
$10.1-20.0$ & 13 & & & & & \\
$20.1-30.0$ & 20 & & & & & \\
$30.1-40.0$ & 7 & & & & & \\
$40.1-50.0$ & 4 & & & & & \\
$50.1-60.0$ & 4 & & & & 1 & \\
$60.1-70.0$ & 4 & & & & & \\
$70.1-80.0$ & 0 & 1 & & & 1 & \\
$80.1-90.0$ & 3 & & & & 1 & \\
$90.1-100.0$ & 1 & & & & 1 & \\
$100.1-110.0$ & 4 & & & & 1 & \\
$110.1-120.0$ & 2 & & & 1 & 1 & \\
$120.1-130.0$ & & & & & & \\
$130.1-140.0$ & & & & & & \\
$140.1-150.0$ & & & & 1 & & \\
$150.1-160.0$ & & & & & & \\
\hline
\end{tabular}

${ }^{1}$ Number of sera. 
Table 3. Results of enzyme-linked immunosorbent assay (ELISA) and the latex agglutination (LA) test with respect to 100 porcine sera examined for toxoplasma antibodies.

\begin{tabular}{lcc}
\hline \multirow{2}{*}{$\begin{array}{l}\text { ELISA } \\
\text { result } \\
\text { (EIU) }\end{array}$} & \multicolumn{2}{c}{ LA test result } \\
\cline { 2 - 3 }$<0$ & negative & positive \\
\hline$<.1-10.0$ & 151 & \\
$10.1-20.0$ & 14 & \\
$20.1-30.0$ & 12 & 1 \\
$30.1-40.0$ & 18 & 2 \\
$40.1-50.0$ & 8 & \\
$50.1-60.0$ & 2 & 1 \\
$60.1-70.0$ & 2 & 2 \\
$70.1-80.0$ & 1 & 3 \\
$80.1-90.0$ & 1 & 1 \\
$90.1-100.0$ & 1 & 2 \\
$100.1-110.0$ & & 1 \\
$110.1-120.0$ & & 5 \\
$120.1-130.0$ & 1 & 2 \\
$130.1-140.0$ & & 2 \\
$140.1-150.0$ & & \\
$150.1-160.0$ & & 2 \\
\hline
\end{tabular}

${ }^{1}$ Number of sera.

values of 70.0 or more were positive in 1,2 or all of the reference tests (Fig. 2). Two of these sera were positive only in IFAT, giving EIU values of 85.0 and 119.1 and IFAT titres of 40 and 300 , respectively.

Of the 52 sera giving EIU values from 10.1 to $70.0 \mathrm{EIU}$, approximately half (27) were negative in all the reference tests, and none of these sera was positive in all of them (Fig. 2). Seven (13\%) of these sera were positive in 2 reference tests, IFAT and the LA test, and $18(35 \%)$ in 1 reference test, 16 of them IFAT and 2 the LA test.

Altogether 56 sera were negative in the IFAT, IHAT and LA tests, giving ELISA EIU values ranging from 0 to 62.0 (Fig. 2), a mean of 13.7 EIU and a median of 9.1 EIU. $70 \%$ of the negative sera gave EIU values ranging from $<0$ to 20.0 and $89 \%$ from $<0$ to 30.0 .

The inter-test reproducibility of ELISA was evaluated by running the low positive control serum from pig 132 times on separate days, and the intra-test reproducibility by examining this same low positive control serum 32 times within the same test runs. The mean, standard deviation, minimum and maximum in the inter-test runs were 43.3, 9.8, 27.3 and 69.8 EIU and those the intratest runs 43.2, 5.1, 32.9 and 53.8 EIU, respectively.

\section{Discussion}

The results obtained by the different methods developed for detecting toxoplasma antibodies are influenced by the stage of infection and the antigen preparation used (Camargo et al. 1978, Lövgren et al. 1987, Verhofstede et al. 1987, Mineo et al. 1980). IFAT employs whole cells of the parasite as an antigen, while the antigenic material in ELISA, IHAT and the LA test consists of the soluble parts of disrupted trophozoites. In spite of this, ELISA has been reported to correlate well with IFAT for detecting toxoplasma IgG antibodies (Walls et al. 1977, Balsari et al. 1980, Violand et al. 1982, Filice et al. 1983). IFAT detects antibodies which appear at the early stage of infection against antigenic components of the membrane of intact trophozoites (Karim \& Ludlam 1975), whereas ELISA antibodies appear later in the course of infection (Oliver et al. 1983). This may be one explanation for the situation seen in Table 1, where some sera with low ELISA values have relatively high IFAT titres. These presumably represent sera from an early stage of infection.

The LA test is simple and rapid to perform, but does not distinguish immunoglobulin classes as ELISA and IFAT do. The 3 sera 
Agreement

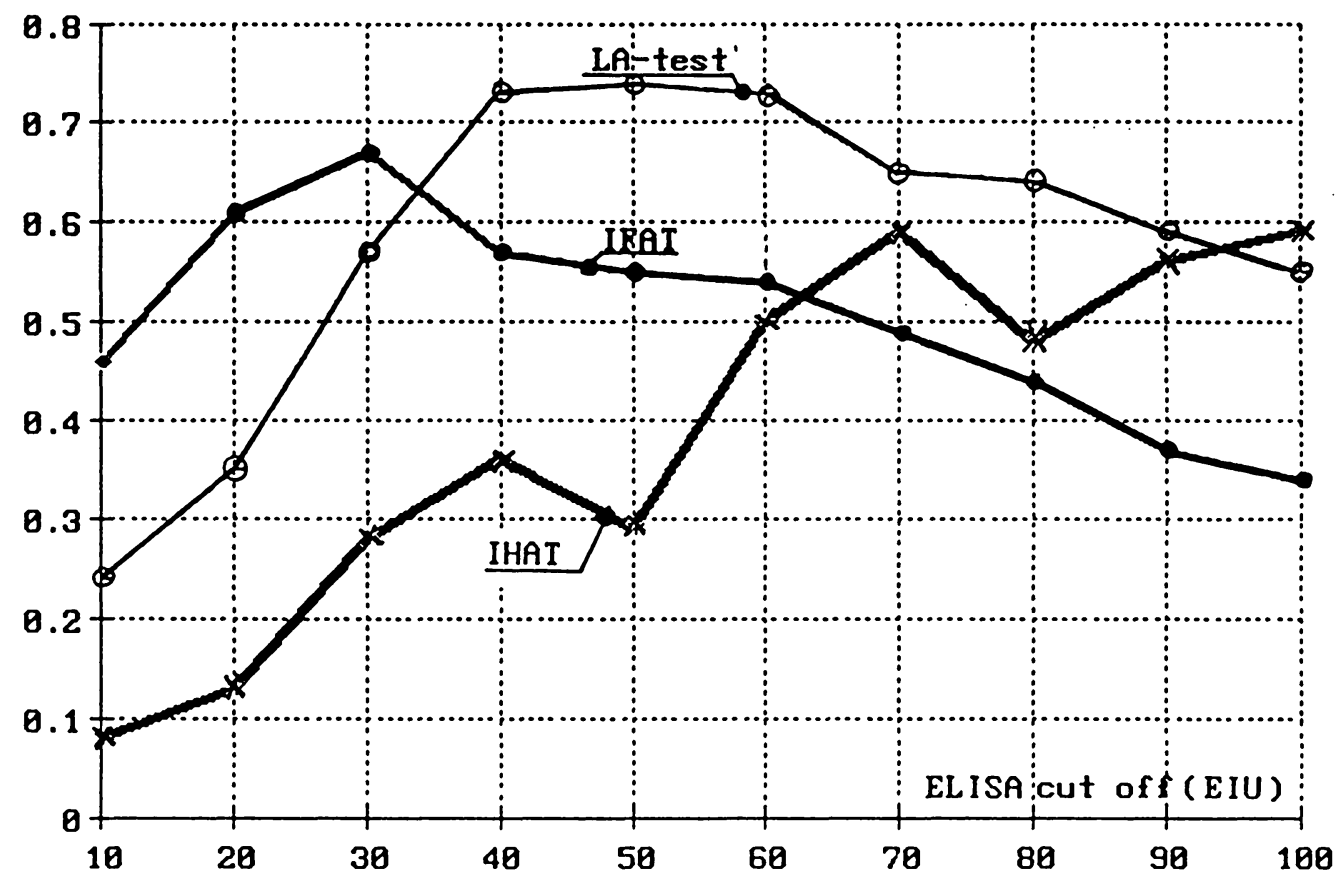

Figure 1. Agreement between ELISA and IFAT, IHAT and the LA test. The extent of the agreement is assessed according to Martin et al. 1987.

with $>70$ EIU which were negative in the LA test (Table 3) are difficult to explain. Two of them presumably represent recent infections.

The sensitivity of IHAT was lower than that of ELISA and the other tests. None of the sera with $<70$ EIU was positive in IHAT, but 2 sera with 110.1-120.0 EIU were still negative in IHAT (Table 2). IHAT has been reported to show fluctuation in titres during the course of infection when detecting toxoplasma antibodies in swine sera (Oliver et al. 1983); to be extremely difficult to read ( $\mathrm{Wil}$ son et al. 1987); and to be a poor test for diagnosing swine toxoplasmosis (Waltman et al. 1984). On the other hand, it is mentioned elsewhere as being a useful test for the detection of latent toxoplasma infection in swine (Katsube et al. 1972, Boch et Neurohr 1982).

The reproducibility of ELISA has been considered good (Woodward 1982, Lin et al. 1980, Walls et al. 1977, Tomasi et al. 1986, van Loon \& van der Veen 1980), although some authors report occasional inter-test variation (Woodward 1982). The intra-test reproducibility was not very good here. The standard deviation was 5.1 (coefficient of variation $11.8 \%$ ) and major differences between 2 wells in the same microtitre plate were found in some cases (minimum 32.0, maximum 53.8 EIU). The standard deviation in the inter-test runs was 9.8 EIU (coefficient of variation $22.6 \%$ ), figures that would presumably have been lower if the number of samples tested had been higher. 


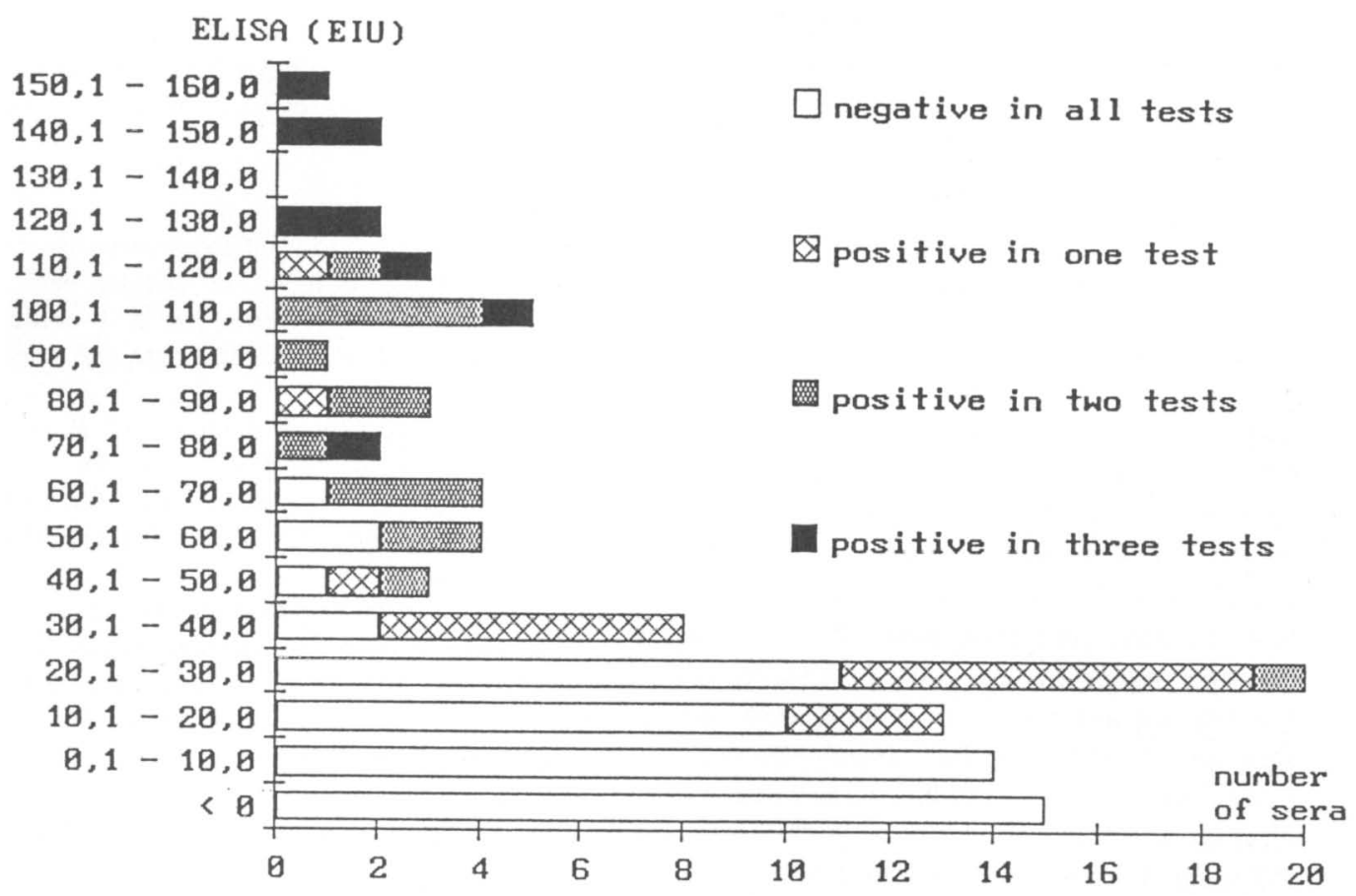

Figure 2. Distribution of the results of IFAT, IHAT and the LA test with respect to 100 swine sera in relation to the ELISA results. The column between 0-10 EIU includes sera giving 0.1-10.0 EIU, that column between 10-20 EIU sera with 10.1-20.0 EIU etc.

The quality of the polystyrene microtitre plates may effect the reproducibility of ELISA results (Chessum \& Denmark 1978, van Loon \& van der Veen 1980). Chessum \& Denmark found that the antigen attached itself unevenly to the plates in some batches, readings for the same sample on some plates differing more than $10 \%$ from the arithmetic mean in most of the wells. Use of such plates for diagnostic serology would lead to erratic results. ELISA is highly sensitive, but it also seems to be sensitive to all kinds of changes in procedure, which may influence the reproducibility of the results (Voller et al. 1976).

ELISA test results can be expressed in various ways, e.g. as end-point titres, absorbance values, ratios of the optical density of the test sample to that of the negative control serum, or comparisons with a standard curve for positive control sera (Burrells \& Dawson 1982). This variety makes it difficult to compare the results obtained by different authors (Wilson et al. 1987). The need for standardization of both the test itself and the mode of expressing the results has been emphasized (Uggla 1986, van Loon \& van der Veen 1980). The availability of good control sera of known toxoplasma antibody titres for each species would be of great help in attempting to render the results of different selfmade ELISA systems comparable. Even though animals with a low positive titre may harbour toxoplasma tissue cysts, it is true that the higher the antibody titre is, the greater is the possibility of a latent infec- 
tion (Work 1967, Katsube et al. 1972, Hellesnes et al. 1978). Results < 10 EIU in the present ELISA procedure were negative, and results $>70$ EIU were positive, as ascertained from the reference tests (Fig. 2). About half of the sera with 10.1-70.0 EIU were positive in IFAT or the LA test or both, and the rest were negative. The agreement between ELISA and IFAT was best with a cut-off of 30 EIU and that between ELISA and the LA test with a cut-off of 50 EIU and there was some fluctuation in agreement values between ELISA and IHAT (Fig. 1). It is difficult to find a satisfactory cut-off for ELISA which will produce as few false negative and false positive results as possible. When this test is used for screening toxoplasma antibodies in porcine sera, all sera giving 10.1-70.0 EIU should be confirmed with a test which has a good specificity, e.g. IFAT.

Although ELISA has been reported to be a rapid, sensitive and easily performed test for routine serology and for screening of toxoplasma antibodies (Walls et al. 1977, Camargo et al. 1978, Woodward 1982, Waltman et al. 1984, Pallangyo et al. 1985, Uggla 1986), it has also been considered technically more difficult than LA, IHAT or IFAT (Wilson et al. 1987). The performance of ELISA needs special equipment and a skilled staff. These may be readily available in laboratories working daily with serology, but scarcely in abattoirs, the laboratories of which are equipped mainly for the performing of sensory and bacteriological analysis.

\section{Acknowledgement}

I wish to thank Ms. Anneli Salonen and Ms. Ritva Kauppi for their skilful technical assistance. My warm thanks to Prof. Jorma Hirn, Prof. Jaakko Tuomi, Dr. Pirjo Veijalainen and lic. vet. med. Matti Aho for their criticism of the manuscript. This work was supported financially by the Vete- rinary Department of the Ministry of Agriculture and Forestry, the Finnish Cultural Foundation, the Finnish Veterinary Science Foundation and Oy Hoechst Fennica Ab.

\section{References}

Anonymous: Serodiagnosis of toxoplasmosis, rubella, cytomegalic inclusion disease, herpes simplex. Immunology series No. 5, Procedural guide. Center for Disease Control, Atlanta 1980.

Balsari A, Poli G, Molina V, Dovis M, Petruzzelli $E$, Boniolo A, Rolleri E: ELISA for toxoplasma antibody detection: a comparison with other serodiagnostic tests. J. clin. Pathol. 1980, 33, 640-643.

Boch J, Neurohr B: Vorkommen latenter Toxoplasma-Infektionen bei Schweinen in Süddeutschland und deren Nachweis mit IFAT und IHAT. (Latent toxoplasma infection in pigs in southern Germany and diagnosis using the indirect fluorescent antibody test and the indirect haemagglutination test). Tierärztl. Umschau 1982, 37, 820-826.

Boch J: Toxoplasma - und Sarcocystis-Infektionen der Haustiere. (Toxoplasma and sarcocystis in domestic animals). Wien. Tierärztl. Mschr. 1973, 60, 337-341.

Burrels $C$, Dawson AMcL: ELISA methodology: variations in technical procedures. In: Wardley RC, Growther JR (eds.): The ELISA: enzyme-linked immunosorbent assay in veterinary research and diagnosis. Martinus Nijhoff Publishers. London 1982, p. 1-9.

Camargo ME, Ferreira AW, Mineo JR, Takiguti $C K$, Nakahara OS: Immunoglobulin $\mathrm{G}$ and immunoglobulin $M$ enzyme-linked immunosorbent assays and defined toxoplasmosis serological patterns. Infect. Immun. 1978, 21, 55 $-58$.

Chessum BS, Denmark JR: Inconstant ELISA. Lancet 1978, 21, 161.

Dubey JP, Murrell KD, Fayer R, Schad GA: Distribution of Toxoplasma gondii tissue cysts in commercial cuts of pork. J. Amer. vet. med. Ass. 1986, 188, 1035-1037.

Felice $G$, Meroni $V$, Carnevale $G$, Olliaro $P, C a$ rosi $G$ : Comparison of ELISA and indirect im- 
munofluorescence in the detection of IgG and IgM antitoxoplasma antibodies. Boll. 1st sieroter. Milan. 1983, 62, 445-450.

Hellenes I, Mohn SF, Melhuus B: Toxoplasma gondii in swine in south-eastern Norway. Acta vet. scand. 1978, 19, 574-587.

Hutchison WM, Dunachie JF, Siim JC, Work K: Coccidian-like nature of Toxoplasma gondii. Brit. med. J. 1970, 1, 142-144.

Karim KA, Ludlam GB: The relationship and significance of antibody titres as determined by various serological methods in glandular and ocular toxoplasmosis. J. clin. Pathol. 1975, 28, 42-49.

Katsube $Y$, Hagiwara T, Imaizumi $K$, Hanaki $T$, Nobuto $K$ : Reliability of the dye and modified hemagglutination tests for the latent infection of Toxoplasma. Jap. J. vet. Sci. 1972, 34, 123-133.

Lin TM, Halbert SP, O'Connor GR: Standardized quantitative enzyme-linked immunoassay for antibodies to Toxoplasma gondii. J. clin. Microbiol. 1980, 11, 675-681.

Luft BJ, Remington JS: Toxoplasmic encephalitis. J. inf. Dis. 1988, 157, 1-6.

Lövgren $K$, Uggla A, Morein B: A new approach to the preparation of a Toxoplasma gondii membrane antigen for use in ELISA. J. vet. Med. B 1987, 34, 274-282.

Martin SW, Meek AH, Willeberg P: Veterinary Epidemiology. Iowa State University Press, Ames, Iowa 1987, 343 p.

Mineo JR, Camargo ME, Ferreira $A W$ : Enzymelinked immunosorbent assay for antibodies to Toxoplasma gondii polysaccharides in human toxoplasmosis. Infect. Immun. 1980, 27, 283287.

Oliver DG, Dreesen DW, Prickett MD, Waltman $W D$, Poy DS, Blue JL: Comparative study of enzyme-linked immunoassay with standard serological tests for the diagnosis of toxoplasmosis in swine. Proc. 3rd Int. Symp. of World Association of Veterinary Laboratory Diagnosticians, Ames, Iowa 1983, pp. 163170.

Pallangyo KJ, Suzuki H, Fukumoto Y, Matsumoto $K$ : One point dilution enzyme-linked immunosorbent assay (ELISA) for Toxoplasma gondii seroepidemiological surveys. Tohoku J. exp. Med. 1985, 147, 349-356.

Tomasi JP, Barka N, Stadtsbaeder S: Serodiagnosis of human $\mathbf{G}$ and $M$ immunoglobulins to Toxoplasma gondii by ELISA using whole tachyzoites as antigens: a comparative study with the indirect haemagglutination (IHA) and immunofluorescence (IFA) tests. Med. Microbiol. Immunol. 1986, 175, 261-269.

Turunen HJ: Detection of soluble antigens of Toxoplasma gondii by a four-layer modification of an enzyme immunoassay. J. clin. Microbiol. 1983, 17, 768-773.

Uggla A: Toxoplasma gondii in farm animals. Some immunodiagnostic methods and their potential use. Thesis. Swedish University of Agricultural Sciences, Uppsala 1986, pp. 56.

van Loon AM, van der Veen J: Enzyme-linked immunosorbent assay for quantitation of toxoplasma antibodies in human sera. J. clin. Pathol. 1980, 33, 635-639.

van Knapen F, Franchimont JH, van der Lugt G: Prevalence of antibodies to toxoplasma in farm animals in the Netherlands and its impli cation for meat inspection. Vet. Quarterly 1982, 4, 101-105.

Verhofstede C, Sabbe L, van Renterghem $L$ : Ability of enzyme-linked immunosorbent assays to detect early immunoglobulin $G$ antibodies to Toxoplasma gondii. Eur. J. clin. Microbiol. 1987, 6, 147-151.

Violand SA, Mitchell TG, Kleeman KT: Comparison of an enzyme-linked immunoassay and a quantitative indirect fluorescent antibody test for detecting antibodies to Toxoplasma gondii. J. clin. Microbiol. 1982, 16, 341-344.

Voller A, Bidwell DE, Bartlett A, Fleck DG, Perkins $M$, Oladehin $B$ : A microplate enzymeimmunoassay for toxoplasma antibody. J. clin. Pathol. 1976, 29, 150-153.

Walls $K W$, Bullock SL, English DK: Use of the enzyme-linked immunosorbent (ELISA) and its microadaptation for the serodiagnosis of toxoplasmosis. J. clin. Microbiol. 1977, 5, 273 -277 .

Waltman WD, Dreesen DW, Prickett MD, Blue $J L$, Oliver DG: Enzyme-linked immunosorbent assay for the detection of toxoplasmosis 
in swine: Interpreting assay results and comparing with other serologic tests. Amer. J. vet. Res. 1984, 45, 1719-1724.

Wilson $M$, Ware DA, Walls $K W$ : Evaluation of commercial serodiagnostic kits for toxoplasmosis. J. clin. Microbiol. 1987, 25, 22622265.

Woodward BC: Evaluation of an enzyme-linked immunosorbent assay specific for human immunoglobulin $G$ as a screening test for detecting anti-Toxoplasma antibodies. J. clin. Microbiol. 1982, 16, 367-372.

Work $K$ : Isolation of Toxoplasma gondii from the flesh of sheep, swine and cattle. Acta Pathol. Microbiol. scand. 1967, 71, 296-306.

\begin{abstract}
Sammanfattning
Evaluering av ELISA för undersökning av antikroppar mot Toxoplasma gondii hos svin.

ELISA (enzyme-linked immunosorbent assay) jämförs med IFAT (indirect fluorescent antibody test), IHAT (indirect haemagglutination test) och LA (latex agglutination) test för att mäta antikroppar mot Toxoplasma gondii i sera av 100 svin.

Alla sera med $<10$ EIU var negativa med andra tester och alla med $>70$ EIU var positiva med 1 , 2 eller 3 av de andra testerna. Hälften av sera med 10-70 EIU var positiva med andra tester och hälften var negativa. Det bästa "cut-off" värdet för ELISA var 30 EIU jämfört med IFAT och 50 EIU jämfört med LA test. Om man vill undvika fel positiva resultat med ELISA, borde alla sera med 10-70 EIU testas med t. ex. IFAT.

ELISA är sensitiv och lämplig för undersökning av stora mängder prov. Det kan ändå vara tekniskt för svårt att utföra på slakterilaboratorier, vars kapacitet är inriktad mest på bakteriologiska och sensoriska undersökningar.
\end{abstract}

(Received September 8, 1989; accepted January 4, 1990).

Reprints may be requested from: Varpu Hirvelä-Koski, National Veterinary Institute,

Regional Laboratory Oulu, P. O. Box 517, SF-90101 Oulu, Finland. 